UCRL- 87287

PREPRINT

\title{
MASTER
}

\section{NEUTRON-INDUCED FISSION-CROSS-SECTION MEASUREMENTS AND CALCULATIONS OF SELECTED TRANSPLUTONIC ISOTOPES}

\author{
R. M. White \\ Lawrence Livermore National Laboratory \\ Livermore, CA 94550 \\ J. C. Browne \\ Los Alamos National Laboratory \\ Los Alamos, NM 87545 \\ This paper was prepased for subriittal \\ to the Nuclear Data for Science and Technology \\ International Conference, Antwerp, Belgium \\ 6-10 September, 1982
}

August 27, 1982

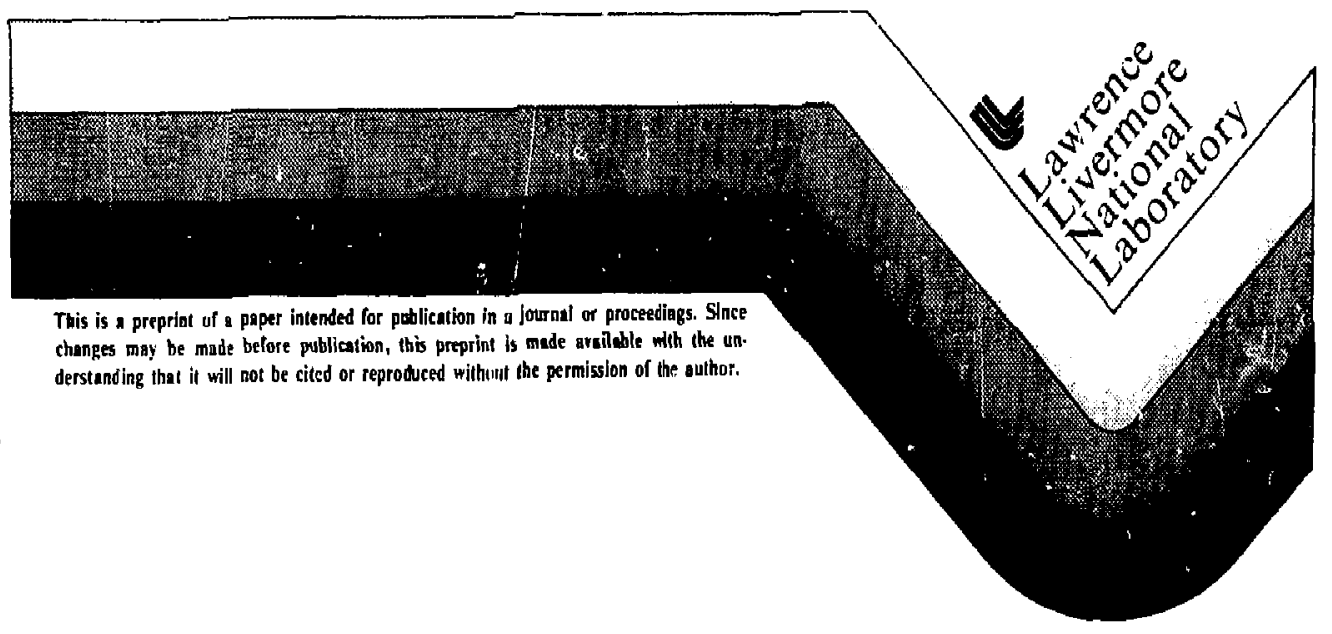

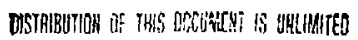



SELECTED TRANSPLUTONIC ISOTOPES'

$$
\text { R. M. White }
$$

Lawrence I.ivermore National Laboratory Livermore, CA 94550

\title{
J. C. Hrowne
}

Los Alamos National Laboratory Los Alanos. N 87545

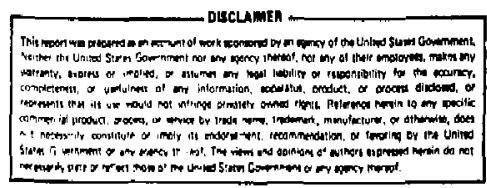

\begin{abstract}
The neutron-1nduced fission cross sections of $242 \pi \mathrm{Am}$ and 24 . range of $10^{-4}$ eV to $\sim 20 \mathrm{MeV}$ in a series of experiments at thi focilities during the past several years. The combined results of these asurements, in wich only sub-nilligram quantities of enriched isolopes were uscd, yield cross sections with uncertainties of approximately $5 \%$ below 10 HeV relative to the $235 \mathrm{U}$ slandard cross section used to nomalize the data. We sumarize the resonance analysis of the $242 \mathrm{~m} / \mathrm{m}\left(\mathrm{n}_{1}, 1\right)$ cross section in the $\mathrm{eV}$ region. Hauser-Feshbach statistical calculations of the delailed fission cross sections of $235 \mathrm{U}$ and $245 \mathrm{Cm}$ have been carried out over the energy region from 0.1 to $5 \mathrm{MeV}$ and these results are compared wi th our experimenlal data.

$\left[242 \mathrm{~m} \mathrm{Am}(n, f),{ }^{245} \mathrm{Cm}(n, f)\right.$. fission cross section measurements, $E_{n}=10^{-3}$ eV to $20 \mathrm{MeV} ;{ }^{235} \mathrm{U}(n, f)$. ${ }^{245} \mathrm{Cm}(n, f)$, Hauser-Feshbash stat istical calculations, $E_{n}=100 \mathrm{keV}$ to $\left.5 \mathrm{MeV}\right]$
\end{abstract}

\section{Introduction}

A series of measurements of the neutron-induced lission cross sections of $242 \mathrm{~min}$ and ${ }^{245} \mathrm{Cm}$ have been carried out at three facjlities during the past several years (sce Table 1). These measurements span an energy range of $10^{-4}$ to $2 \times 10^{+7}$ ev. In this report we sumbrize the results of the low energy $242 m_{\text {Am }}$ resonance analysis and thel outline the resulls and comparisons of our high energy (MeV) measurements with previously reported dala. Hauser-Feshbach stalistica! colculalions of the fission cross section over the energy region of the fission neutron spectrum are discussed and results of these calculations for the ${ }^{235} \mathrm{C}$ and ${ }^{245} \mathrm{Cm}$ ? ission cross sections are presented.

Table 1. Summary of experimental areasurenents on the netron-induced fission cross sections of ${ }^{212 n_{A m}}$ and ${ }^{245} \mathrm{Cm}$ at variaus facililies since 1977.

\begin{tabular}{|c|c|c|c|}
\hline YEAR & FACILITY & ISOTOPE & ENERGY RANGE (EV) \\
\hline 1977 & LLNL-Linac' & $242 \mathrm{~m} A \mathrm{~m}$ & $10^{-2}-2 \times 10^{+7}$ \\
\hline 1978 & LLNL-Linae & $\begin{array}{l}242 \mathrm{~m}_{\mathrm{Am}} \\
245 \mathrm{Cm}^{\dagger \dagger}\end{array}$ & $\begin{array}{l}10^{-4}-2 \times 10^{+7} \\
10^{-4}=2 \times 10^{+7}\end{array}$ \\
\hline 1980 & LANL-HNR' & $\begin{array}{l}242 \mathrm{~m} / \mathrm{m} \\
245 \mathrm{Cm}\end{array}$ & $\begin{array}{l}\sim 10^{+6}=\sim 10^{+7} \\
\sim 10^{+6}=\sim 10^{+7}\end{array}$ \\
\hline 1960 & LLNi-IГT & $\begin{array}{l}242 \mathrm{Am} \\
245 \mathrm{Cm}\end{array}$ & $\begin{array}{l}14.1 \mathrm{HeV} \\
14.1 \mathrm{HeV}\end{array}$ \\
\hline
\end{tabular}

thivermore 100-HeV Electron Linac, Ref. I.

Thivermore 100-MeV Electron Linac, Ref. 2

tLos Alamos Heapons Neutron Research Facility

"tLivermore Insulaled Core Transformer Accelerator

\section{Experimenta! Techniques}

The experimental techniques of the 1977 and 1978 Linac measuremenls, as well as preliminary statistical analysis of the low energy resonance parameters of both $242 \mathrm{a}_{\mathrm{Am}}$ and ${ }^{24} \mathrm{C} \mathrm{Cn}$, have been reported

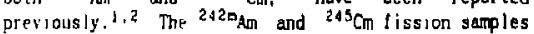
used in these mxusurements were prepared by the LLNL Nuclear Chemstry Division and rere electroplated on $0.05 \mathrm{~mm}$ thick hemispherically shaped ionization chambers. As the sarules mere extremely radioactive with a-decay, the hemispherical geanetry helped to differentlate between the a-decay and fission signals by limiting the path-length of alphas and lission fragnents through the gas in the tission chambers, Table Il gives the pertinent data on the fission samples used.

Until 197\%, the only high energy data on $242 m_{A m}$

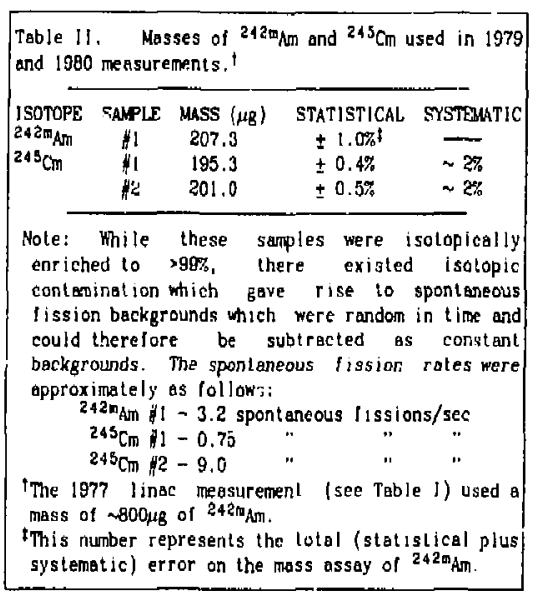

were those of Seeger el al. ${ }^{3}$ and Bowmen et al. ${ }^{4}$ In 1977 Browne of al. ${ }^{1}$ measured the $242 \mathrm{~m}_{\mathrm{Am}}\left(\mathrm{n}_{1} f\right)$ cross solinn. to $20 \mathrm{HeV}$. We repeated this measurement in 1979 (see Table 1) with a new semple and in the same experiment measured the ${ }^{246} \mathrm{Cm}(\mathrm{n}, t)$ cross section using two different samples (see Table II). Addilionrl meastrements of the $242 \mathrm{~m} A m(n, f)$ and $245 \mathrm{Cm}(n, f)$ cross sectinns were subsequenlly carried out al the los Alamos Weapons Neutron Research (WNR) Iacility (see Table 1) to verily the Livermore Linac results in the $\sim$ to $\sim 10$ HeV region. Bolh faculilies provided a "whites source of neutrons and standard tirne-of-flight techniques were used to determine incident neutron energies. For these high energy measurements and for thermal energies, the cross sections were measured relative to the cross section of ${ }^{235} \mathrm{U}$. In the resonance region, the neutron llux shape was measured with thin lithiun glass detectors and the relative cross gections obtanned were then normalized to the thermal data, an overlap check with the high energy doia, measured independently with respect to ${ }^{20 S} U$, was then made in each case. Table III surmarizes the ertors for the $2+2 m \operatorname{mm}(n, f)$ and ${ }^{245} \mathrm{Cm}(\mathrm{n}, 1)$ final data sels relative to the ENDF/B-V ${ }^{235} U(n, 1)$ oross section used to normalize these data.

Resonanance Analysis of $242 \mathrm{~m}$ Am(n, l)

Results of a Breit-Higner sum-of-single-level 
Table III. Surmary of statistical and systematict errors for ${ }^{242 "} \mathrm{Mm}(\mathrm{n}, 1)$ and ${ }^{245} \mathrm{Cm}(\mathrm{n}, 1)$ cross section measurements at the Livermore Linac.

\begin{tabular}{|c|c|c|}
\hline \multicolumn{3}{|c|}{$\begin{array}{l}\text { STATISTICAL ERAOR } \\
\text { Energy } 24 \mathrm{Rm}_{\mathrm{mm}}{ }^{245} \mathrm{Cm}\end{array}$} \\
\hline & 0.5 & 0.7 \\
\hline & $3.5 \%$ & $3.5 \%$ \\
\hline $1 \mathrm{MeV}$ & $0.5 \%$ & 1.17 \\
\hline $14 \mathrm{Me}$ & $2.0 \%$ & $4.5^{\circ}$ \\
\hline
\end{tabular}

tThe known systematic errors evolve from the measured masses of $212 \mathrm{~m} \mathrm{Am},{ }^{245} \mathrm{Cm}$, and the ${ }^{295} \mathrm{U}$ 'stendard' as well as Iram the efluciency of the corresponding fission chamber of each sample.

*stimated uncertanty in efficiency from rission pulse-hesight distribulion and calculalion of percent of fission tragnents lost in sarmple deposit.

analysis of 48 fission resunances in the $242 m A m(n, l)$ cross section up to $20 \mathrm{el}$ are sumarized in Ref. 1 . These data show a complicated structure vith many levels and a lack of any obvious inlerferences. This 1 mplies a large number of Bohr trenstion states (fissian channels) open for this nucleus since the level-level inlerlerence is essentially nonexistent in the case of mary channels. This is further supported by the lact that the distribution of fission widths for these levels follows a general chi-square distribution having at least 10 degrees of freedom. lt is therefors more meaningful to fit these data with a sum of single levels than with a multileve! (R-matr|x) approach which allows for interlerence between levels and which would require any channels per level to fit these data.

The complicated resonance structure in the $242 \mathrm{~m}(\mathrm{n}, f)$ cross section in same regions between ? and 20 el requires a "synthesis' of enough levels to lit the magnlude of the cross section while at the same lime preserving its shepe. Therefore, the average level spacing, $\langle D\rangle$, which we determined to be $0.4 \mathrm{ev}$ is a maximum value since we have almosl certainly missed darrow resonances in this region. When compared with even-even fissioning systems, the

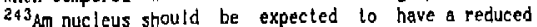
averabe level spacing becuuse the unpaired proton allows population of additional intrinsic excitations without the expenditure of energy necessary to first break a nucleon-nucleon pair. Becouse of the higher level density. The probabilitv of the first resonance occurring lower in neutron energy is more likely. The rirst observed resonance in the $242 m_{A m}(n, 1)$ cross section occurs at $E_{n}=0.178 \mathrm{eV}$. The low energy of this first resonance together with the fact that it also has a very large reduced neutron $\mathrm{x}$ : ich gives $242 r^{\prime}$ Am the largest thermal fission cross section knowm.

\section{Dala Comprison - High Energy Region}

The high energy portions (10 keV to $10 \mathrm{MeV})$ of the 1977 and 1979 Linac measurements of the $212 n_{A m}(n, 1)$ cross section are platted for comparison in FIg. 1. These were independent experiments using different sarmples of $24{ }^{2} \mathrm{~m}_{\mathrm{Am}}$ and the agreement in these two data sets is excellent. Also included in Fig. 1 are the recently published results of Fomshkin el al. ${ }^{6}$

The high erergy portion ( $10 \mathrm{keV}$ ta $10 \mathrm{MeV}$ ) of the 1979 Linac measurement on the ${ }^{245} \mathrm{Cm}(n, f)$ cross section is given in Fig. 2 blong with the previously measured $245 \mathrm{Cm}(n, 1)$ dala of Hoore and Keyworth ${ }^{7}$ wich were derived from a nuclear explosion used as a pulsed neutron source. From $\times 30 \mathrm{eV}$ to $i 00 \mathrm{keV}$ their daib are in very good agrecment with the present measurement and above $100 \mathrm{~kg}$ their data agree tairly weil in shope with the present results.

Because of the poorer statistical quality of the 'hite' neutron source data above $10 \mathrm{MeV}$, an

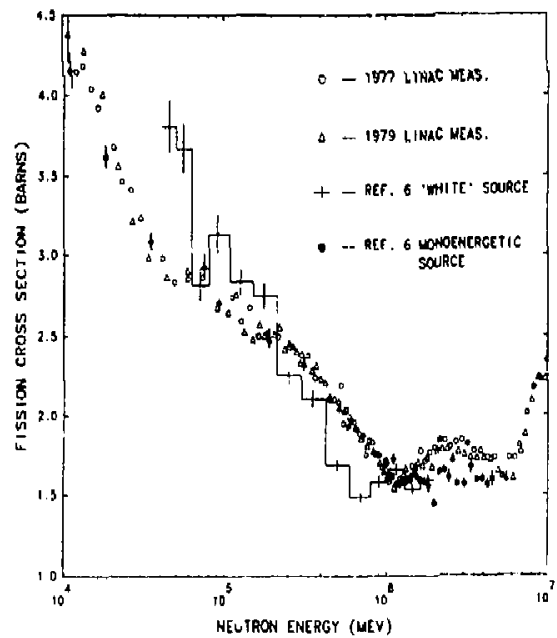

Figure 1. Comparisoh of the 1977 and 1979 Linac messureartats of the $242 \pi$ Am(n,l) erose section. Also included are the recent dat of formighus et al 6

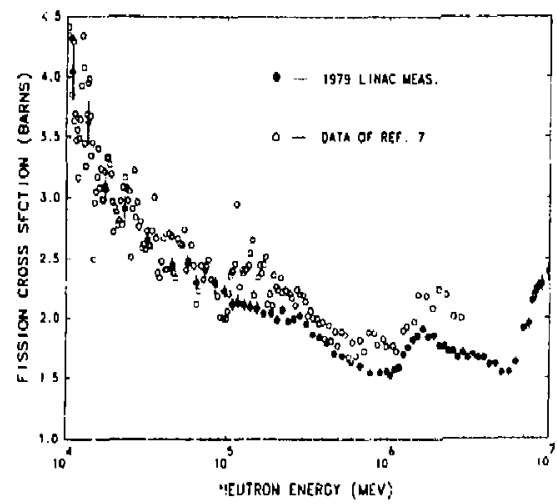

Figure 2. Corperison of our 1979 Linne mezsurement of the high energy ${ }^{243} \mathrm{C}(n, f)$ cross section with the date of Moore and Keyworth, ${ }^{7}$

Indepandent monosuerget ic measuremeal, usung the same fission chambers, was conducted at the LLNL-ICT facility (see Table I). Al the ICT, a pulsed 400-keV deuteron bean was used with a tritiatcd karget to produce an intense llux of neutruns via the ${ }^{3} \mathrm{H}(\mathrm{d}, \mathrm{n})^{4} \mathrm{He}$ reaction. Collimating the neutron flux at $90^{\circ}$ 1.o the incident deutron beam produced a $14.1 \mathrm{MeV}$ neutron beam of minimum energy spread. Time-ol-flight techniques were eqployed to enhance the signal-to-baciground (spontaneous fission) ralio. The values obtained for the Iission cross sections (relative to $336 \mathrm{U}$ ) at 14.1 $\mathrm{HeV}$, along with the $14.8-\mathrm{HeV}$ results of the $242 \mathrm{~m}_{\mathrm{m}}(\mathrm{n}, t)$ measurement of Ref, 6 , are glven in Table IV. As can be seen in the table. the 14-HeV eross secition data for $342 m_{A \pi}(n, 1)$ are in good agrepr-: For both $24 m_{A m}$ and ${ }^{245} \mathrm{Cm}$ these data also agree with our Linac measurements within the experimental uncertainly.

Table IV, Resulls and comparison of Livermore-lCT measurement of $242 \pi_{A m}(n, l)$ and $245 \mathrm{Cm}(n, f)$ cross sections at $E_{2}=14,1$ Hel and $212 \mathrm{mAm}(n, r)$ cross section of Re1. 6 at $\mathrm{E}_{\mathrm{N}}=1 \mathrm{~A} . \mathrm{B} \mathrm{MFV}$.

\begin{tabular}{|c|c|c|c|c|c|}
\hline \multirow{4}{*}{$\begin{array}{l}\text { ISOTOPE } \\
242 \mathrm{~m} A \mathrm{~m}\end{array}$} & \multirow{2}{*}{$\begin{array}{c}\text { PRESENT NOFK } \\
\text { d(a, } 1)\end{array}$} & \multicolumn{2}{|c|}{ ERROR } & \multirow{3}{*}{$\begin{array}{l}\mathrm{REF} .6 \\
\frac{\mathrm{a}(\mathrm{n}, 1)}{2.31 \text { barns }}\end{array}$} & EPPOR \\
\hline & & Slat. & Sys. & & Slat. \\
\hline & 2.41 barns & $5.1 \%$ & $5 \%$ & & $2.2 \%$ \\
\hline & 2.55 barns & $2.8 \%$ & $\sim 5 \%$ & - & \\
\hline
\end{tabular}




\section{Calculation of the Fission Cross Section}

Our present elfort irrolves calculating these fisgion cross sections over the energy region of the fission neutron spectrum ( $100 \mathrm{keV}$ to $\sim 5$ Lev). In this energy region many of the fissile actinides have 'macroscopic' structure clearly seen in the ${ }^{235} \mathrm{U}(\mathrm{n}, \mathrm{r})$ and ${ }^{245} \mathrm{Cm}(n, 1)$ cross sections show below. Bjornholm and Lymo have determined trands in tission barrier parameters over the actinide region. We have mitten a statistica! code, FISCAL, utilizing the ir results. Lo investigate this structure as mell as the general thape and magnitude of the fission cross section in this tnergy region.

For neutron-induced reactions, proceeding through channel $x$. we write the cross section as follows:

$$
s_{n, x}(E)=\sum_{j} a_{c n}^{j \prime}(E) \frac{T_{*}^{\prime *}}{\sum_{E} T_{e}^{\prime *}}
$$

where $\sigma_{E \rightarrow}^{\mathrm{d}}(E)$ is the compound rucleus formation cross section (for a given $j^{\pi}$ ) writtes:

$$
\sigma_{c n}^{j \pi}(E)=\pi \lambda^{2} g_{j} \sum_{L, S}^{J} T_{L, S}^{J n}(E)
$$

and $\mathrm{j}^{\pi}$ is the lolal compound rucleus angular momentum and parity, $S$ is the chamel spin (neutronttarget) and $L$ is the orbital angular momentun. For the neutron transmission coeflicients we used the Moldauer $10 \mathrm{rm}^{\theta}$ suggested in Buprnholm and Lynn. $T_{x}$ is the total irunsmission coefficient for the decay of the compound rucleus through channel $x$ and $\sum T_{c}$ is the sum of the total transmission coefficients for decay throuph all channels. The modes of decay important to this work are $(n, n),\left(n, n^{\prime}\right),(n, y)$, and $(n, f)$. Above a few hundred kev the competing decay modes are mainly the inclastic and iission charnels. The total transmission coelficient for elastic/inelastic scattering is rritten:

$$
\begin{aligned}
& T_{n}^{J^{\prime \prime}}(E)=\sum_{L, L, \mathrm{~S}} T_{L, g}^{J{ }^{\prime \prime}}\left(E_{C H^{-t},}\right. \\
& +\sum_{1, L, s}^{1} \int_{E_{d}}^{E_{c u}} T_{i, s}^{d \pi}\left(E_{c n}-c\right) \rho\left(\tau, 1^{n}\right) d \varepsilon
\end{aligned}
$$

where $E_{c y}$ is center-ol-mass energy, $c_{1}$ is the energy of the $i^{\text {th }}$ discrete level in the residual nucleus, and $\rho\left(t, l^{\pi}\right)$ is the level density (used above the known discrele (eve/s) of the residual nucleus. For the gama-decoy channel we used the total transmission coeflicient given in Ret. ob. For the enerizy region considered here, the total transmission costficient for lission is given by:

$$
T_{i}^{j *}=\frac{T_{A}^{J^{*}} \cdot T_{B}^{J *}}{T_{A}^{J^{*}}+T_{B}^{J "}}
$$

where $A$ and $B$ are the inner and outer barritirs of the double-humped fission barier and

$$
\begin{aligned}
& T_{A}^{\prime \prime}=\sum_{i} \frac{1}{1+e^{-2 \pi\left(\varepsilon_{x}-\varepsilon_{a}-\varepsilon_{1}\right) / h \omega_{A}}} \\
& +\int_{E_{d}}^{\infty} \frac{p\left(c_{1} J^{\pi}\right)}{1+e^{-2 \pi\left(E_{1}-E_{A}-t\right) / h u_{l}}} d t
\end{aligned}
$$

where the sum is over discrete barrier leveis (fisgion channeis) and the integral is the contriloution from higher levels. $E_{A}$ is the barrier helght, $E_{x}$ is the excitation of the coapound nucleus and a aimilar expression hoids for barrier $B$.

\section{Calculation of the 235 (n, I) Crose Section}

To test our corte and to explore the senaitivity of the calculated cross section to the virious input paraneters, we chose to start with the best-knom fission cross section, $235(n, 1)$, and have used the recent evaluation of Poenitzio as our standard relerence data. For the inelastis channel, 93 (discrete) levels ${ }^{11}, 12$ up to $1 \mathrm{HeV}$ in excilation were included for the residual 2ast nucleus. Not all of these levels (particularly above $500 \mathrm{keV}$ ) have know spin and parity but a plot of the spin distribution of the known (and tentatively knom) spins yintded a spln dispergion coefficlent consistent ith ou. Therefore. levels of unknown spin were assigned spins consigtent with a spin dispersion coefficient os. Above [ HeV, a level density representation of the Gilbert-Cameron cunstant lemperature form, ${ }^{13}$

$$
\rho\left(E, I^{n}\right)=C(2 t+1) e^{-\left(1+\frac{t}{t}\right)^{2} / 2 \theta^{2}{ }_{e} E / \theta}
$$

was employed. Values for $C, \theta$, and 0 were taken fron Rel. 8 as were the paraneters for the garma changel which employed the samk form.

For the fisson channel, the barrier reference paranelers, $E_{A}=5.63 \mathrm{HeV}, w_{A}=1.04 \mathrm{HeV}, E_{0}=5.53 \mathrm{HeV}$. $h_{w_{B}}=0.6 \mathrm{HeV}$, of Ref, a were used. The rission barrier level densities were represented by the constant temperature lorm given above, with several temperature regions (see. Ref, g) employed for each barrier. However, in order lo calculato the detailed cross section, it wat found neccssary to replace the 'shape' of the barifier level densities reprerented by the several constont lemperoture regions with a level density lunction which meintained that general shape and which had a continuous first derivalive. 14 The resulting calculation for the ${ }^{205} \mathrm{U}(\mathrm{n}, \mathrm{f})$ cross section is plotted in Fig. 3. No width fluctuetion correction, which will reduce the cross section betow a MeV in the fission channel, 15 is yet incorporated in this calculacion.

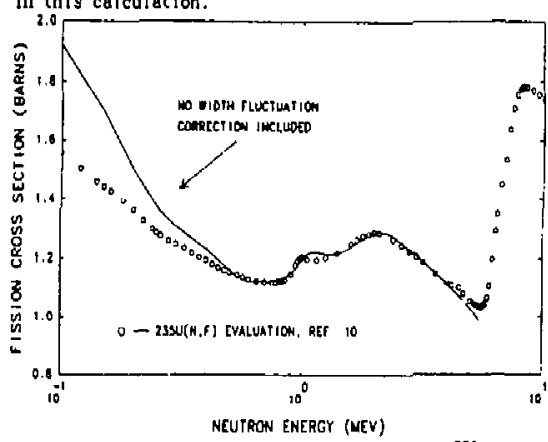

Figure 3. Hauserfleshbach calculotions of the 234 $(n, f)$ cross seclion compared to the evaluation of Poenitz.

The step in the ${ }^{235} \mathrm{U}(\mathrm{n}, \mathrm{f})$ cross sertion between $800 \mathrm{keV}$ and I Mev is aboul $8 \%$ and, wile the exact shape is not well known, the fact that this 'macroscopic' structure really exists is clearly seen in the various lission dala sets on $205 \mathrm{U}$ (see for example Ref. 10). This structure appears in the calculation because the decreasing fission cross section up to $\sim \mathrm{MeV}$ is governed mainly by the increasing inelastic scattering cross section which is compting with fission. The shape of the increasing inelastic crosy section with energy is governed by the increasing number of levels in the residual $235 \mathrm{~J}$ nucleus to which the neutron can inelastically scatter. Therefore, it the fission cross section is to be calculated correctly in this region, it is very important to represent the discrete levels in $295 \mathrm{U}$ up to $1 \mathrm{HeV}$ as complete as possibje. From $\sim 1.5$ to 45 $\mathrm{LeV}$, the level density in the residual ${ }^{235} \mathrm{U}$ nucleus appears to be represented satisfactorily by constant temperature form using the parameters of Bjornhola and Lynn. However, it our representation of the discrete Jevels is reasonable, then there exists structure in the level density in the $1 \mathrm{MeV}$; egion of excitation in ${ }^{235} \mathrm{U}$ in ordor for our discrete representation to the cnto' the constemt telperature form wich itis the data at bigher energies. This structure is seen, to a greater or lesser degree, in the level density representations of B/fraholm and byn in the $1-3,4$ 
repion of excitation above the fission barriers in 230. Withoul this struclure in the level density our calcuiation would not reprodice the dafaled $23 b_{y}(n, t)$ cross section.

\section{Calcu! dit 1on of the ${ }^{2+5} \mathrm{Cm}(\mathrm{n}) 2$ ) Cross Sectron!}

ler the initial calculation of the $24 \operatorname{com}(n, l)$ cross section, we mainlutned the same level density partenters as in the $2351(n, f)$ ralculation and used the barrier parameters, $E_{A}=5.7 \mathrm{MeV}, f_{w_{A}}=1.04, E_{0}=4.2$ MeV. $h_{B}=0.6 \mathrm{Mel}$. of Bjprnholm and Lynn $10 \mathrm{r}{ }^{2}{ }^{6} \mathrm{Cm}$. $W_{1}$ !h these parameters, we calculated the cross section lo be in qualilative apreemenl with the mapnitude of the mensured crose sectlon $(r 1.7$ barss) in the region. However. Lhe detalled shape was completely wrone lie should not expecl thr level densities used for the 235 calculation to lit the detall of the 24 Cniln.t) gross seclion. Since less $15 \mathrm{knnmin}$ nbuut the discrete fevels up $10-1 \mathrm{MeV}$ in ${ }^{245} \mathrm{Cm}$ thall in 239 . He allowed the shape of the level densily in the residunl disch liuleles lo sary while mantaining the sume lission hatrici level donsulles as used in the 33 licalcitiotion. The hescht of the ouler barrier. $\mathrm{E}_{\mathrm{B}}$. in $246 \mathrm{Cm}$ wis also chatuged if $4.5 \mathrm{~kg}$ to $\mathrm{fll}$ the reasured cress sevion better. The results of the final adculation are slowh in fig. twith no width lluctuation forrection yel Included in the code. As

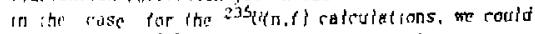
only lit the ${ }^{245} \mathrm{Cm}(\mathrm{n}, 1)$ dala by allowing some structiore in the level defislty representation of the

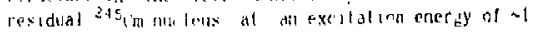

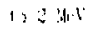

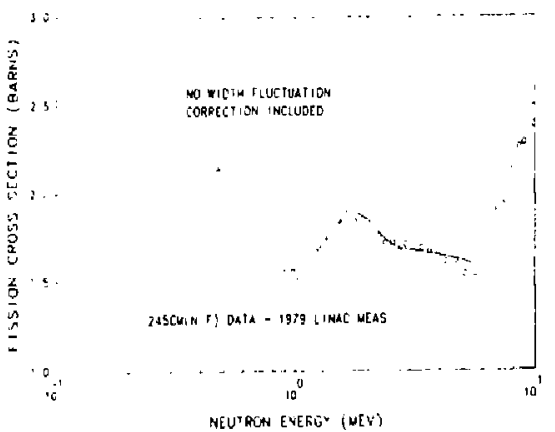

ficure t. Hnuser-Feshbarti calrulat ion of $1 \mathrm{~h} \cdot{ }^{2+5} \mathrm{Cm}(\mathrm{m}, \mathrm{ll})$ apos act tioll ompared to cur icog Linal measurement.

Conc는 므:

He have completed measurements of the $242 \mathrm{~m}$ am and $24 \mathrm{Cm}$ lission cross sectlons [rom thermal energies lo $\sim 20 \mathrm{MeV}$ in a series of experiments at several facililies. These measurements were accomplished to good accuracy with sub-rilligram quantilies of isotopically entriched $2+2 \mathrm{~m}_{A \pi}$ and ${ }^{245} \mathrm{Cm}$.

hauser-Feshbach calculatious have been carried out wich reasonably represent the detolled 2351 and ${ }^{345} \mathrm{Cm}$ I Ission cross sections in the energy range from $t$ to $5 \mathrm{MeV}$. Our calculalions do not yet include a width lluctuation correction nor do they include a second chance fission calculation. We have been puided in this calculational effort mainly by paramelerizations of Bjprnhoim and Lynn. Our calculat:ons indicate that, in order lo reproduce the detalled cross section. we require level density functions which have cont unuous 1 irst derivalives and which con:ain sone structure in both the residual and compound nucleus in the lower energy region of excilation.

thile we conclude fron these calculations that the 'macroscopic' structure seen in the 1 lo $2 \mathrm{NAV}$ region of these fission cross sections is most likely cassed by structure in the level densities. we cannol postlively rule out the possibility of this structure entering through the lission (barrier) transmission coellicients. If indeed this were the case, i.e., that the macroscopic struclure were really intermediate structure, our present methor of alrulaling the tolol fission Iransaission would not produce 1t, It seems unlikely that such inlermediate structure should be present at an excilatian of 2 lo 3 Net above the fission bariers.

There exist two inportant arnas in which our calculalians are beine impraved beyond tha existing Iimitalions discussed above. The first is in the calculation of the neutron transmissitin roelficients and the compound nucleus formation cross section. Neutron transmission coefficients calculated from a deformed optical potential which will lit the lotal cross sections over a range of aclinides and over the energy region of interesl here should improve the energy dependence of these roefficienls and give a more physically realislic compound reaction crose section. The second area of improvement ard probably the more inportant one is 10 calculate correclly the level densitv (intrinsic and collective) to at least a low beV both at ground stale delormation lor the larget nucleus and al delormations corresponding to the two barriers in thr compound nucleus. It is essential that these density calculalions be included If re allempt to use statistical calculations to accuratcly predict those cross sertions for whish masurements are nol now leasible.

\section{Acknowledpmenls}

He appreciale the efforts of $R$. H. Hoff and the LLWt, Nuclear Chemisiry Division far their contributions to the preparalion of the transplutionis fission samples. Our thanks are also due to G. F. suchampaugh and P. H. Lisowisk I who collaborated in the WNR measurement. R. E. Howr conlribuled greatly 10 all phases of the measurentents at both inboratories. Discussions with $H$. Marshal! Blann. D. G. Madiand and E. D. Arthur vere very helpful laward our calculational ellort. Finally, special appreciation is due to R. E. Stroul. It of LLNL whose programing ahilify made difficult calculations a joy 10 perform.

\section{References}

1. J. C. Browne, plal., "Fission Cross Sechon lor

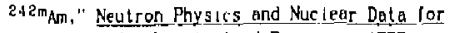
Rénctors and other Applied Purposes, AERE, Harwell, gi7 (1979).

2. R. M. Thite, el al., "Fission Cross Seclion of ${ }^{24} \mathrm{Cm}$ Irom $10^{-3} \mathrm{eV}$ to $10^{4} \mathrm{eV}$. "Nisc lear Cross Seclions for Technology. MAs Special Publiration 594, (Kлoxw /1e, TY, 1979), p. 496

3 P. A. Seeger, ct at , Nucl. Phvs A96, 605 (1967)

4. C. 5. Bownan, el al.. Phys. Rev. 166. l'l9 (1968).

5. J. C. Browne and R. M. While, "The C29mAm Fission Cross Seclion," to be published.

6. E. F. Fonushkin. et al., Yadernaya Fızıka 33, 620 (198!).

7. W. S. Moore and G. A. Keyworth. Prys. Rev, C 3. (656 (197!).

6. 3. Budralusian and J. F. Lynn, Rev. Mod Phys. 52 . $72 \div(1980)$.

9. P. A. Moldawer. Phys. Rev $\frac{157}{255} 907$ (1967).

10. W. P. Poenitz. "Evaluation ${ }^{\frac{205}{5}} \mathrm{U}(r, 1)$ Between $100 \mathrm{keV}$ and $20 \mathrm{MeV}$." Argonne Nat $10 \pi \mathrm{al}$ Laboralory Reporl, ANL/NDH-45 (1879).

II. C. M. Lederer and V. S. Shirley, eds., Table of Isolopes, $7^{\text {th }}$ Edition. John Hiley and Sons. New York, NY (1978).

12. M. R. Schmorak, shuclear Data Sheers 21. 117 (1977).

13. A. Gilberl and A. G. H, Cameron, Can, J. Phys. 43 , 1446 (1865).

14. F. N. Fritsch and R. E. Carlson. "Konotone Piecewise Cubis interpolalion," SIAM J. Numer Anel, 1?. $238(1980)$.

15. E. D. Arthur, "Use of the Statistical Model for the Calculation of Conpound hucleus Contributions to the Ithalastic Scat tering of actinide Muclei," Los Alamos Nationa) Loboratury Report. LA-UR 81-3497 (1981) 


\section{DISCL.AIME.R}

This document was prepared as an account of work sponsoned by an agency of the \& inited States Government. Neither the United States Government nor the I'niversily of California nor any of their employecs, makes any Harranty, "vpress ur implied, or assumes any legal liability or responsibility lor the accuracy, completeness, or usefulness of any information, apparatus, product, or process fisclosed. of represents that iss use would not infringe privately ownted rights. Referencs herein to any specific commercial produsts, priseess, of enes icte hy trade name, trademark, manufacturcr, of otherrise, does not necessarily conslitute or imply its cndorsement, recommendariun, or favoring by the I nited States Covernment or the Liniversity of Califorria. The views and opinions on authors expressed herein do not necessarily state ar reflect those of the $\mathbf{I}$ nit sd States Goremment thereof, and shall not be used for advertising or prodsct endorsement purposes. 
Technical Infurmation Diparment - Lawrence Livermore I.aboratory University of Cahifornia - Livermorc. Califurnia 94550

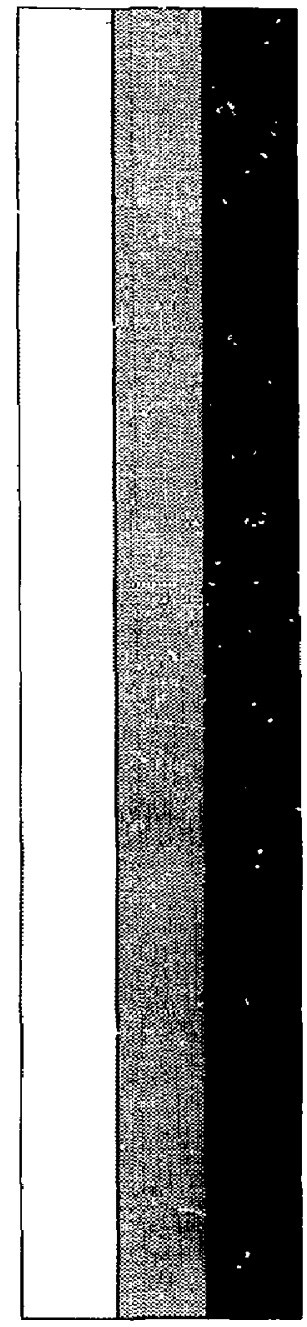

